\title{
Grass pollen season in selected cities of Poland in 2019
}

\author{
Katarzyna Dąbrowska-Zapart', Kazimiera Chłopek ${ }^{1}$, Agnieszka Lipiec², Małgorzata Puc ${ }^{3}$, \\ Małgorzata Malkiewicz ${ }^{4}$, Krystyna Piotrowska-Weryszko ${ }^{5}$, Dariusz Jurkiewicz ${ }^{6}$, Grzegorz Siergiejko \\ Adam Rapiejko ${ }^{8,}$, Ewa Kalinowska ${ }^{8}$, Piotr Rapiejko ${ }^{6,8}$
}

${ }^{1}$ Faculty of Natural Sciences, Institute of Earth Sciences, University of Silesia in Katowice, Poland ${ }^{2}$ Department of Prevention of Environmental Hazards and Allergology, Medical University of Warsaw, Poland

${ }^{3}$ Institute of Marine \& Environmental Sciences, University of Szczecin, Poland ${ }^{4}$ Laboratory of Paleobotany, Department of Stratigraphical Geology, Institute of Geological Sciences, University of Wroclaw, Wroclaw, Poland

${ }^{5}$ Department of Botany and Plant Physiology, University of Life Sciences in Lublin, Poland ${ }^{6}$ Department of Otolaryngology with Division of Cranio-Maxillo-Facial Surgery in Military Institute of Medicine, Warsaw, Poland ${ }^{7}$ Pediatrics, Gastroenterology and Allergology Department, University Children Hospital, Medical University of Bialystok, Poland ${ }^{8}$ Allergen Research Center, Warsaw, Poland ${ }^{9}$ Oxford Archaeology Ltd., Oxford, England

Abstract:

The pollen of grass is the primary trigger of pollen allergies during the summer months. It causes some of the most severe and difficult-to-treat symptoms. During the flowering of grass, over $90 \%$ of patients allergic to grass pollen suffer from allergic conditions. The symptoms caused by grass pollen allergens appear in some patients after exceeding the concentration of 20 grains in $\mathrm{m}^{3}$ of air.

The aim of this study was to compare Poaceae pollen seasons in 2019 in 11 cities located in different regions of Poland. Pollen monitoring was conducted in Bialystok, Bydgoszcz, Sosnowiec, Lublin, Olsztyn, Szczecin, Piotrkow Trybunalski, Warsaw, Opole, Zielona Gora and Wroclaw. Airborne pollen was monitored by the volumetric method using Burkard or Lanzoni pollen samplers. Pollen season length was determined by the $98 \%$ method, where the start of the season was defined as the date when $1 \%$ of the seasonal pollen total was trapped and the end of the season as the date, when $99 \%$ of the seasonal pollen total was reached.

The pollen season start date was recorded earliest in Zielona Gora (April 27 $7^{\text {th}}$ ), latest in Szczecin (May 25 $5^{\text {th}}$ ). The highest grass pollen concentration values were found in Lublin, Piotrkow Trybunalski and Warsaw, whereas the lowest ones in Bialystok. The annual grass pollen sum was highest in Lublin (4715 pollen grains), whereas it was lowest in Bialystok (1256 pollen grains). A relatively high pollen count was also recorded in Warsaw (4106 pollen grains) and Zielona Gora (4077 pollen grains). The longest grass pollination season was recorded in Zielona Gora (139 days) and the shortest in Szczecin (110 days). In the remaining measuring points, grass pollen in the air maintained from 112 to 131 days. The highest grass pollen allergen risk occurred in Lublin, Olsztyn and Zielona Gora and the lowest in Bialystok.

Key words: allergens, pollen count, grass (Poaceae), Poland, 2019

$\mathrm{T}$ he grass family, belonging to the monocotyledon class, includes over 10 thousand species, with nearly 200 growing in Poland [1]. The following family contains the most valuable crop species for humans, which are the basic source of food. The taxonomic diversity of grasses causes that their flowering period is long and it lasts from April to October [2], making pollination season also long. Grass pollen in 
the atmospheric air are present for many months [3]. The first grains of grass pollen appear in the atmosphere in the last decade of April, but due to very low concentration (single grains) they do not pose a clinical threat. During the flowering of grass, over $90 \%$ of patients allergic to grass pollen suffer from allergic conditions [4]. The symptoms caused by grass pollen allergens appear in some patients after exceeding the concentration of 20 grains in $\mathrm{m}^{3}$ of air, and in all patients allergic to grass pollen at a concentration exceeding 50 grains in $\mathrm{m}^{3}$ of air. Exposure to a concentration of 120 grains in $\mathrm{m}^{3}$ of air causes severe allergic symptoms from the lower respiratory tract and dysfunction of other organs [5]. Grass pollen allergens are the most common cause of allergic diseases in our climate. Cross reactions are noted between pollen allergens of all species within the family, as well as after consumption of beans, soybeans and peanuts $[6,7]$.

Aim

The aim of this study was to compare grass pollen seasons in 2019 in selected cities of Poland.

\section{Material and method}

In 2019 monitoring of airborne grass pollen was carried out in Bialystok, Bydgoszcz, Sosnowiec, Lublin, Olsztyn, Szczecin, Warsaw, Piotrkow Trybunalski, Opole, Wroclaw and Zielona Gora. Airborne pollen concentrations were investigated by the volumetric method using Burkard or Lanzoni pollen samplers. Microscopic observations were performer on slides obtained in a 7-day cycle with assessment of 24-hour periods. Pollen concentrations were expressed as the number of pollen grains in $1 \mathrm{~m}^{3}$ of air per day $\left(\mathrm{P} / \mathrm{m}^{3}\right)$. The start of the season was defined as a date when $1 \%$ of the seasonal cumulative pollen count was trapped and the end of the season when cumulative pollen count reached $99 \%$. The total pollen count over this period was expressed by the symbol SPI (Seasonal Pollen Index). The study results are presented in graphs and shown in a table (figs 1-6, tab. 1).

\section{Results and discussion}

In most of the cities, the grass pollen season in 2019 started in the first or second decade of

Table 1. Characteristics of grass (Poaceae) pollen season in 2019.

\begin{tabular}{|c|c|c|c|c|c|c|}
\hline Site & $\begin{array}{l}\text { Duration of pollen } \\
\text { season (number } \\
\text { and days) }\end{array}$ & $\begin{array}{l}\text { Peak value } \\
{\left[\mathrm{P} / \mathrm{m}^{3}\right] \text { and }} \\
\text { peak date }\end{array}$ & $\begin{array}{l}\text { Annual } \\
\text { pollen } \\
\text { sum (SPI) }\end{array}$ & $\begin{array}{l}\text { Number of days } \\
\text { concentration above } \\
\text { threshold } 20 \mathrm{P} / \mathrm{m}^{3}\end{array}$ & $\begin{array}{l}\text { Number of days } \\
\text { concentration above } \\
\text { threshold } 50 \mathrm{P} / \mathrm{m}^{3}\end{array}$ & $\begin{array}{l}\text { Number of days } \\
\text { concentration above } \\
\text { threshold } 120 \mathrm{P} / \mathrm{m}^{3}\end{array}$ \\
\hline Bialystok & $\begin{array}{c}20.05-13.09 \\
117\end{array}$ & $\begin{array}{c}47 \\
10.06\end{array}$ & 1256 & 23 & 0 & 0 \\
\hline Bydgoszcz & $\begin{array}{c}17.05-19.09 \\
126\end{array}$ & $\begin{array}{c}92 \\
6.06\end{array}$ & 2528 & 41 & 18 & 0 \\
\hline Sosnowiec & $\begin{array}{c}9.05-10.09 \\
125\end{array}$ & $\begin{array}{c}170 \\
26.06\end{array}$ & 3444 & 46 & 28 & 3 \\
\hline Lublin & $\begin{array}{c}18.05-6.09 \\
112\end{array}$ & $\begin{array}{c}301 \\
23.06\end{array}$ & 4715 & 52 & 32 & 7 \\
\hline Olsztyn & $\begin{array}{c}15.05-9.09 \\
118\end{array}$ & $\begin{array}{c}103 \\
18.06\end{array}$ & 3514 & 52 & 32 & 0 \\
\hline Szczecin & $\begin{array}{c}25.05-11.09 \\
110\end{array}$ & $\begin{array}{l}104 \\
6.06\end{array}$ & 2453 & 41 & 16 & 0 \\
\hline Piotrkow Trybunalski & $\begin{array}{c}10.05-11.09 \\
125\end{array}$ & $\begin{array}{l}127 \\
6.06\end{array}$ & 3441 & 43 & 27 & 1 \\
\hline Warsaw & $\begin{array}{c}5.05-12.09 \\
131\end{array}$ & $\begin{array}{l}112 \\
1.06\end{array}$ & 4106 & 48 & 34 & 0 \\
\hline Opole & $\begin{array}{c}4.05-11.09 \\
131\end{array}$ & $\begin{array}{c}121 \\
18.06\end{array}$ & 3607 & 44 & 33 & 1 \\
\hline Zielona Gora & $\begin{array}{c}27.04-12.09 \\
139\end{array}$ & $\begin{array}{c}143 \\
26.06\end{array}$ & 4077 & 51 & 35 & 2 \\
\hline Wroclaw & $\begin{array}{c}1.05-23.08 \\
115\end{array}$ & $\begin{array}{c}176 \\
26.06\end{array}$ & 3314 & 42 & 25 & 3 \\
\hline
\end{tabular}


Figure 1. Grass pollen count in Bialystok and Bydgoszcz in 2019.

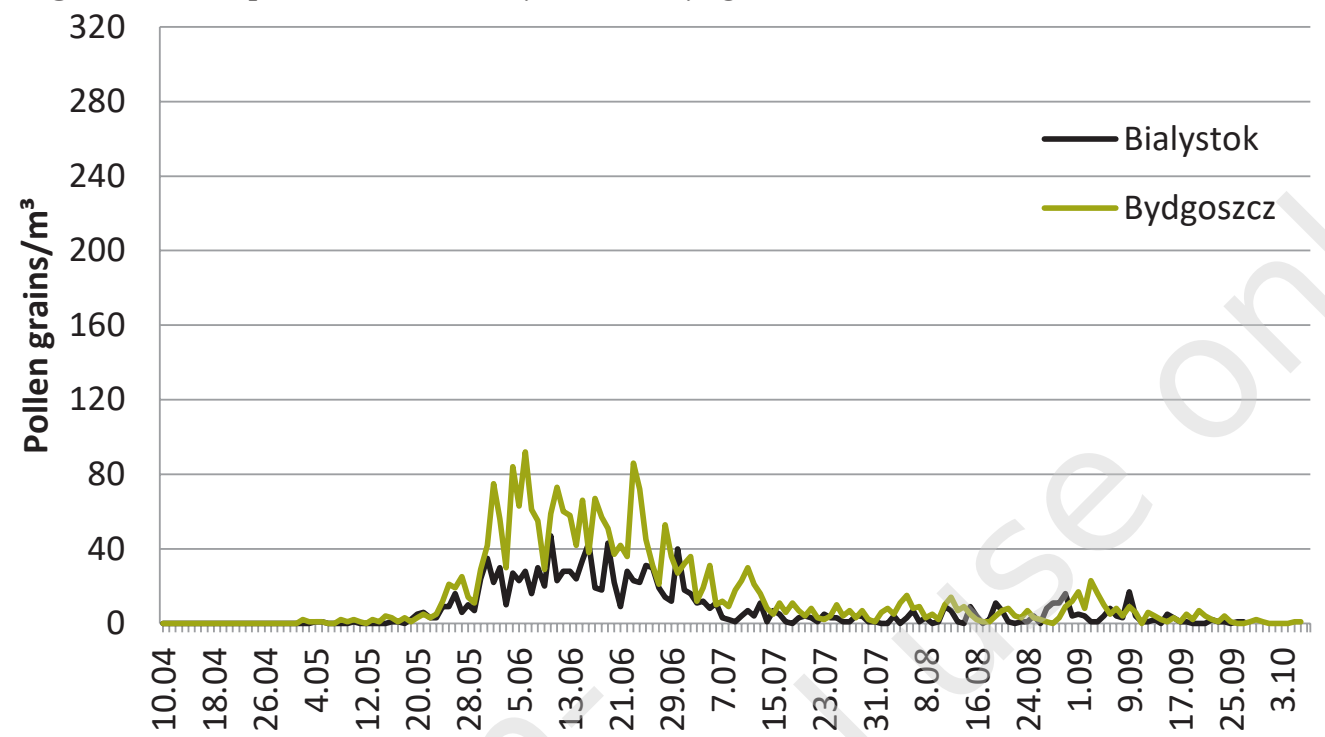

Figure 2. Grass pollen count in Sosnowiec and Lublin in 2019.

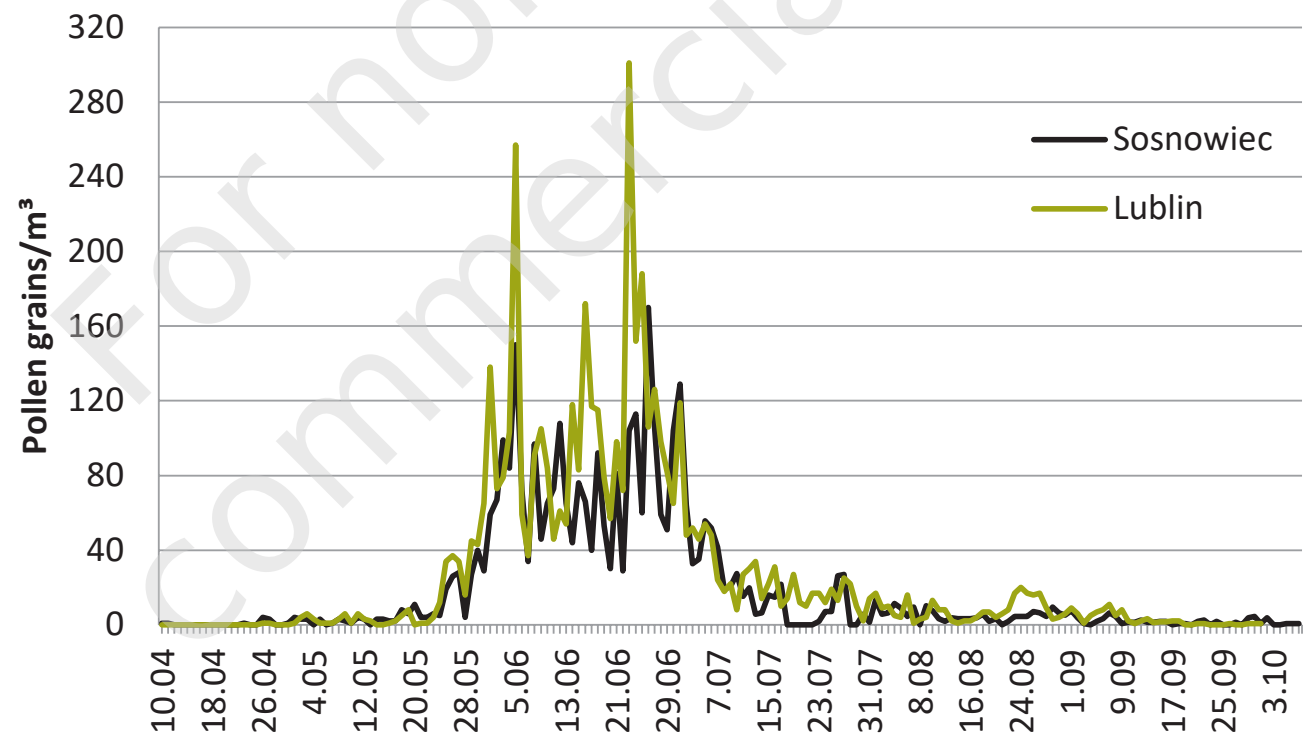

Figure 3. Grass pollen count in Olsztyn and Szczecin in 2019.

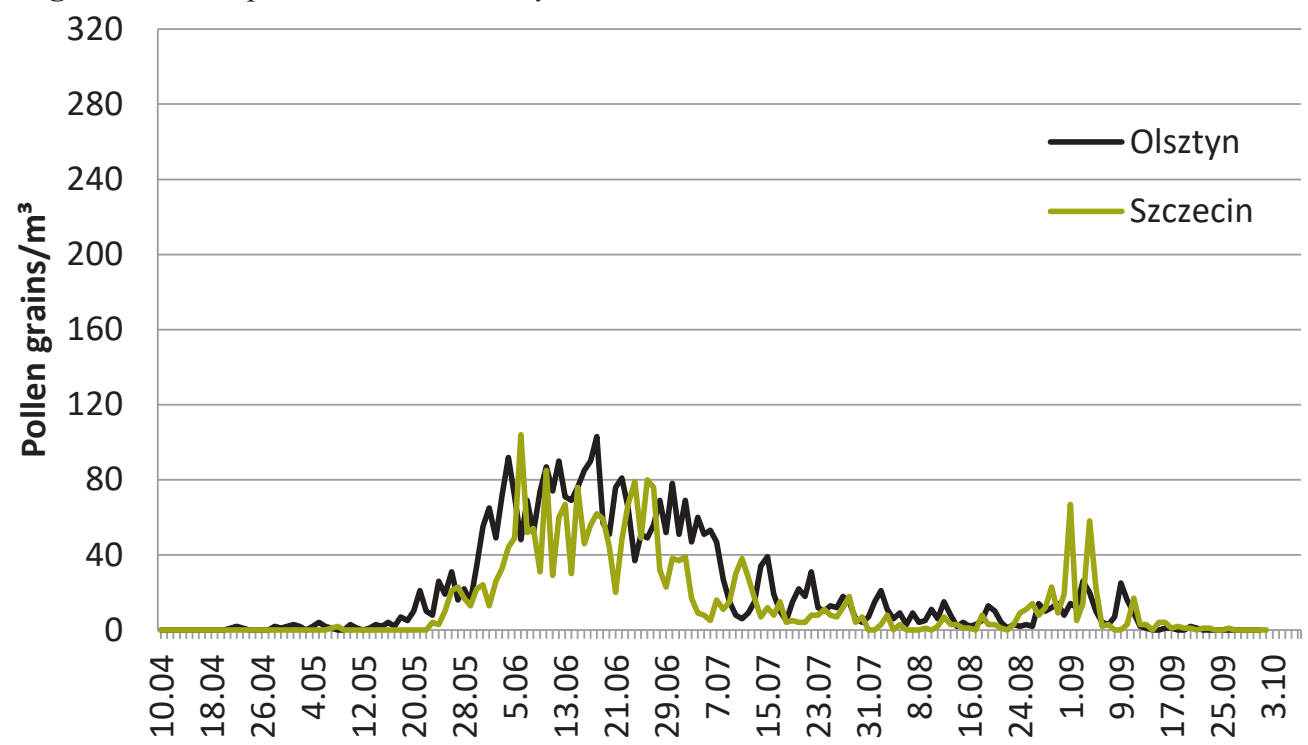


Figure 4. Grass pollen count in Warsaw and Piotrkow Trybunalski in 2019.

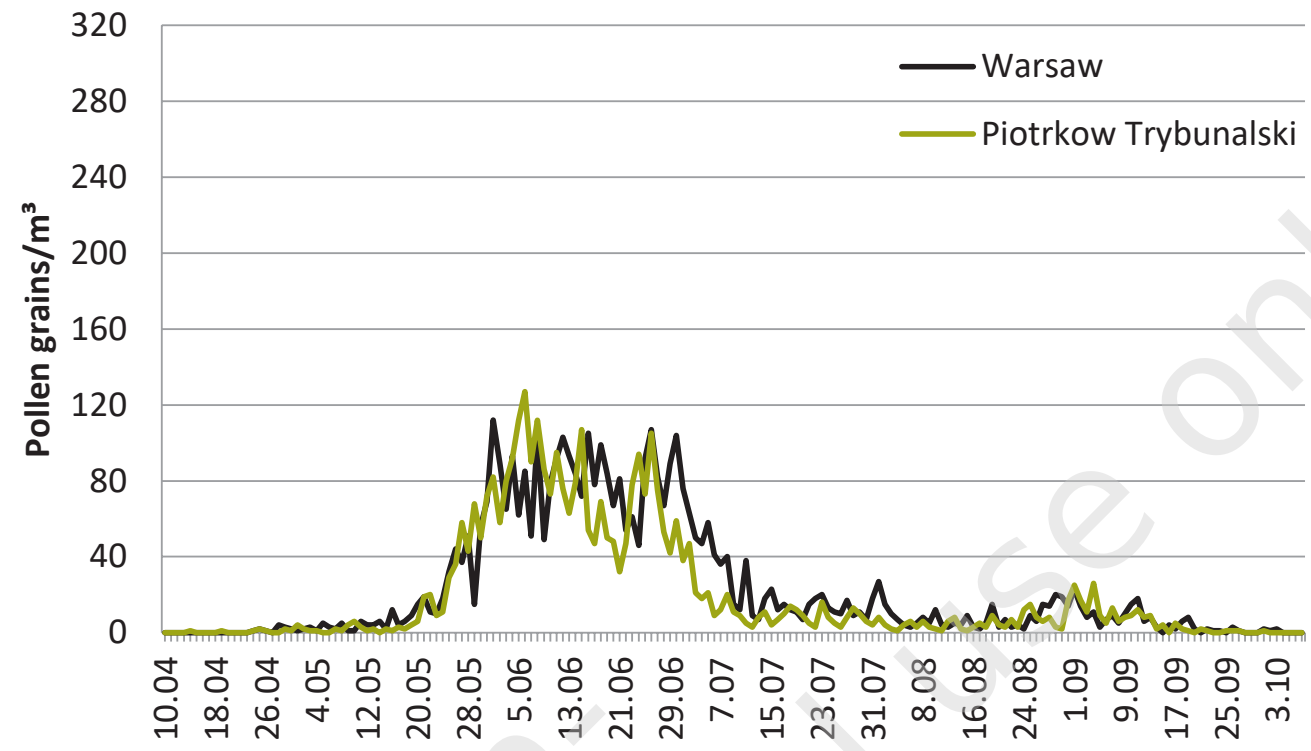

Figure 5. Grass pollen count in Wroclaw, Opole and Zielona Gora in 2019.

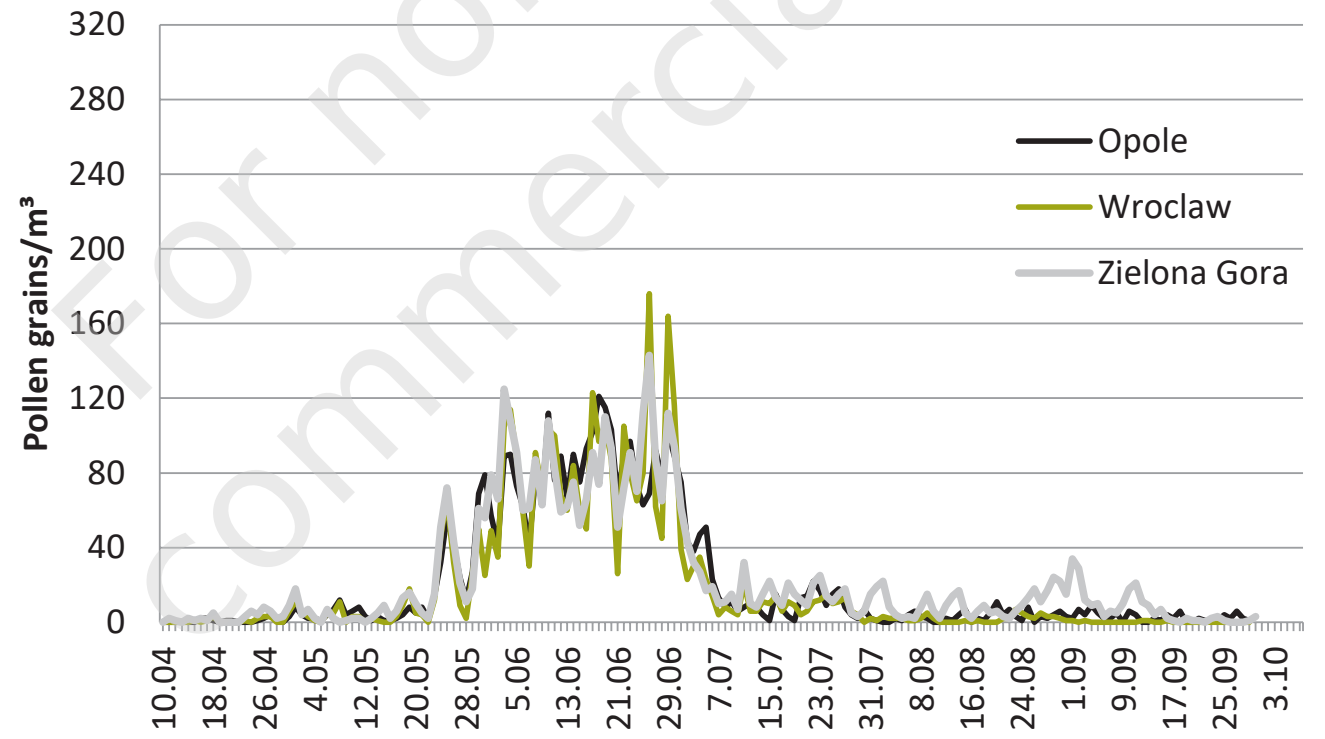

May (tab. 1). The earliest pollen season start was recorded in Zielona Gora (April 27 ${ }^{\text {th }}$ ), whereas the latest one in Szczecin (May 25 $5^{\text {th }}$ ). The grass pollen season in 2019 started in all cities later than in 2018, with the exception of Zielona Gora, where the pollen season started on the same day as the year before (April 27 $7^{\text {th }}$ ) [8]. The end of the grass pollen season was observed between August 23 $3^{\text {rd }}$ (in Wroclaw) and September $19^{\text {th }}$ (in Bydgoszcz) (tab. 1).

The longest grass pollination season was recorded in Zielona Gora (139 days) and the shortest in Szczecin (110 days). In the remaining measuring points, grass pollen in the air maintained from 112 to 131 days. The pollen season of grasses in 2019 was long, but compared to the average of long-term rese- arch in the discussed cities, it did not show any significant differences [8-12].

Maximum daily pollen concentrations ranged between $301 \mathrm{P} / \mathrm{m}^{3}$ and only $47 \mathrm{P} / \mathrm{m}^{3}$, with the highest ones recorded in Lublin and the lowest ones in Bialystok (figs 1, 2), as in 2018 [8]. Our study reveals that in Bydgoszcz, Szczecin and Piotrkow Trybunalski the dates of maximum pollen concentration occurred on June $6^{\text {th }}$ (tab. 1, figs 1, 3, 4) and in Sosnowiec, Zielona Gora and Wroclaw also on the same date June $26^{\text {th }}$ (tab. 1 , figs 2,5$)$. The risk of pollen allergy due to the persistence of pollen concentrations above $20 \mathrm{P} / \mathrm{m}^{3}$ was highest in Lublin and Olsztyn (52 days) and the lowest in Bialystok (23 days) (tab. 1). Significant exposure to grass pollen allergens is demonstrated by the number of 
days with concentrations exceeding $50 \mathrm{P} / \mathrm{m}^{3}$ [5]. Days with such concentration were found most in Zielona Gora, Warsaw, Opole, Lublin and Olsztyn (more than 30 days). In Bialystok, however, no such day was registered (tab. 1). A very high concentration $\left(120 \mathrm{P} / \mathrm{m}^{3}\right)$ have only appeared in some cities (tab. 1, figs 1-6) The highest number of days was recorded in Lublin (7 days) as in 2018 [8].

The annual grass pollen sum was highest in Lublin (4715 pollen grains), whereas it was lowest in Bialystok (1256 pollen grains). A relatively high pollen count was also recorded in Warsaw (4106 pollen grains) and Zielona Gora (4077 pollen grains).

\section{Conclusions}

1. In 2019, the grass pollen season in all the analysed cities started between April 27 $7^{\text {th }}$ (Zielona Gora) and May $25^{\text {th }}$ (Szczecin). The pollen season duration at the investigated monitoring sites was 110-139 days (on average 123 days).

2. The maximum daily concentrations of pollen grains were recorded in Lublin, Piotrkow Trybunalski and Warsaw, whereas the lowest concentrations were noted for Bialystok.

3. In Lublin, the highest annual sum was also found and proportionally to the daily maximum, the lowest annual sum of pollen grains was recorded in Bialystok.

4. The highest grass pollen allergen risk occurred in Lublin, Olsztyn and Zielona Gora and the lowest in Bialystok.

\section{References}

1. Falkowski M. Trawy polskie. Państwowe Wydawnictwo Rolnicze i Leśne, Warszawa 1982.

2. Szafer W, Kulczyński S, Pawłowski B. Rośliny polskie. Wyd. IV. Państwowe Wydawnictwo Nankowe, Warszawa 1976.

3. Weryszko-Chmielewska E (ed). Pytek roślin w aeroplanktonie różnych regionów Polski. Copyright Katedra i Zakład Farmakognozji Wydziału Farmaceutycznego Akademii Medycznej, Lublin 2006.

4. Obtułowicz K, Szczepanek K, Radwan J et al. Correlation between airborne pollen incidence, skin trick tests and serum immunoglobulin in allergic people in Cracow, Poland. Grana 1991, 30: 136-141.
5. Rapiejko P, Lipiec A, Wojdas A, Jurkiewicz D. Threshold pollen concentration necessary to evoke allergic symptoms. Int Rev Allergol Clin 2004, 10(3): 91-93.

6. Hofman T, Michalik J. Alergia pytkowa. Wyd. TOM, Poznań 1998.

7. Rapiejko P, Weryszko-Chmielewska E. Pytek traw. Alergia, Astma, Immunol 1998, 3(4): 187-192.

8. Dąrowska-Zapart K, Chłopek K, Myszkowska D et al. Analysis of the grass pollen season in selected Polish cities in 2018. Alergoprofil 2018, 14(4): 91-95.

9. Weryszko-Chmielewska E (ed). Pyłek roślin w aeroplanktonie różnych regionów Polski. Copyright Katedra i Zakład Farmakognozji Wydzialu Farmaceutycznego Akademii Medycznej, Lublin 2006.

10. Weryszko-Chmielewska E, Piotrowska-Weryszko K, Rapiejko P et al. Analiza sezonu pytkowego traw w 2013 roku w wybranych miastach Polski. Alergoprofil 2013, 9(3): 18-23.

11. Puc M, Kotrych D, Rapiejko P et al. The analysis of grass pollen season in northern Poland in 2016. Alergoprofil 2016, 12(4): 186-189.

12. Rapiejko P, Lipiec A, Puc Met al. The analysis of grass pollen season in northern Poland in 2017. Alergoprofil 2017, 13(4): 154-156. DOI: 10.24292/01.AP.151217.

ORCID

K. Dąbrowska-Zapart - ID - orcid.org/ 0000-0002-8976-7739

A. Lipiec - ID - orcid.org/0000-0003-3037-2326

M. Malkiewicz - ID - orcid.org/0000-0001-6768-7968

M. Puc - ID - orcid.org/0000-0001-6734-9352

K. Piotrowska-Weryszko - ID - orcid.org/ 0000-0003-3827-3218

D. Jurkiewicz - ID - orcid.org/0000-0003-3729-2679

G. Siergiejko - ID - orcid.org/0000-0003-4084-8332

E. Kalinowska - ID - orcid.org/ 0000-0003-4821-6882

P. Rapiejko - ID - orcid.org/ 0000-0003-3868-0294

\section{Author's contributions:}

Dąbrowska-Zapart K.: Sosnowiec aerobiological data, work concept, writing the manuscript, literature review, proofreading;

Chłopek K.: Sosnowiec aerobiological data, preparation of figures and table;

Lipiec A.: Warszawa, Opole aerobiological data;

Puc P.: Szczecin, Bialystok aerobiological data;

Malkiewicz M.: Wroclaw aerobiological data;

Piotrowska K.: Lublin aerobiological data;

Jurkiewicz D.: Piotrkow Trybunalski aerobiological data;

Siergiejko G.: Bialystok aerobiological data;

Kalinowska E.: Olsztyn aerobiological data;

Rapiejko P.: Bydgoszcz, Opole aerobiological data, work concept;

Rapiejko A.: Zielona Gora aerobiological data.

Conflict of interests: The authors declare that they have no competing interests.

Ethics: The contents presented in this paper are compatible with the rules the Declaration

of Helsinki, EU directives and standardized requirements for medical journals.

Corresponding author:

\section{Katarzyna Dąbrowska-Zapart, PhD}

41-200 Sosnowiec, Będzińska 60

tel. (032) 368-94-77

e-mail: katarzyna.dabrowska-zapart@us.edu.pl 